\title{
A study on the effects of sales related factors on brand equity
}

\author{
Naser Azad* and Azadeh Salmantabar
}

MA in Business Management, Department of Management and Accounting, South Branch, Islamic Azad University, Tehran, Iran

\begin{tabular}{|c|c|}
\hline$\overline{C H R O N I C L E}$ & AB S TRACT \\
\hline $\begin{array}{l}\text { Article history: } \\
\text { Received January 4, } 2014 \\
\text { Accepted } 1 \text { June } 2014 \\
\text { Available online } \\
\text { June } 3 \text { 2014 } \\
\text { Keywords: } \\
\text { Brand equity } \\
\text { Factor analysis } \\
\text { Sales effect }\end{array}$ & $\begin{array}{l}\text { This paper presents an empirical investigation to study the effects of sales related factors on } \\
\text { brand equity. The study designs a questionnaire and distributes it among all } 353 \text { sales } \\
\text { representatives who work for a dairy producer in province of Mazandaran, Iran. Using principal } \\
\text { component analysis, seven variables including qualification criteria, motivation, personality, } \\
\text { empowering sales representative, information size, personal characteristics and sales interest in } \\
\text { job on brand equity are extracted. The implementation of structural equation modeling has } \\
\text { confirmed that there were positive and meaningful relationships between seven factors and } \\
\text { brand equity. The highest impact belongs to empowering sales representative followed by } \\
\text { qualification criteria, quantity of information, personality and sales motivation. }\end{array}$ \\
\hline
\end{tabular}

\section{Introduction}

The strategic planning process can be normally linked with corporate goal formulation but it is argued that bigger progress would be constructed in understanding marketing's participation in strategic planning if marketing's role in the goal formulation process can be accomplished. Unfortunately, the extant theories of the firm are inadequate in varying degrees for this purpose. Anderson (1982) proposed a new theory of the firm, which attempts to specify the role of marketing and the other functional areas in the goal setting and strategic planning process. There are literally several methods for sales promotion and management such as sales force automation (SFA) (Barker et al. 2009), which is the implementation of software to automate sales tasks, including sales activities, order processing, customer management, sales forecasting and analysis, sales force management, and information sharing. According to Bente et al. (2012), reputation and seller photos hold a large and equally sized capability for sellers' "face work" in most online transactions. Buehrer et al. (2005) explored the reasons why salespeople use SFA technologies, the perceived barriers to SFA usage and how management may increase the usage of SFA technology.

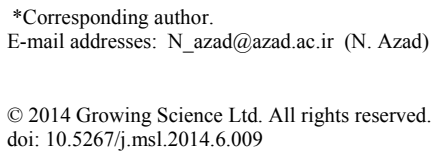


Cascio et al. (2010) introduced a new antecedent to the SFA adoption model, management commitment alignment (MCA) and explained that alignment between top management and immediate supervisors' commitment to the SFA technology played essential role on SFA adoption. Their results indicated that while commitment from both leadership levels seemed to be the most conducive to SFA adoption, misaligned commitment conditions maintained differential impacts on adoption. More specifically, even when supervisors are committed to sales technology, insufficient top management commitment may hurt SFA adoption.

Cho and Chang (2008) empirically investigated the psychological and social antecedents of salespeople's resistance toward SFA technologies in South Korea. They added to the literature on SFA technologies by looking at resistance toward innovation in the post-adoption as well as intraorganizational diffusion stage.

Franke and Park (2006) combined findings from a sample of 155 salespeople to examine alternative methods of antecedents and consequences of adaptive selling behavior (ASB) and customer orientation (CO). They reported that selling experience could increase performance but not job satisfaction, and saleswomen rated their performance and satisfaction bigger than salesmen did. The magnitudes of the relationships in their survey also indicated that ASB and selling experience had bigger impacts than $\mathrm{CO}$ and gender on salesperson performance did.

Gohmann et al. (2005) reported the results of a study, which concentrated on the differences in perceptions held by the United States Army's hiring force and its top-level management toward the Army's newly adopted SFA system, the Army Recruiting Information Support System (ARISS). They reported that substantial differences existed between the perceptions held by the recruiting force and higher level management toward ARISS, the SFA system.

\section{The proposed study}

This paper presents an empirical investigation to study the effects of sales related factors on brand equity. The study designs a questionnaire and distributes it among all 353 sales representatives who work for a dairy producer in province of Mazandaran, Iran. Fig. 1 demonstrates some basic personal characteristics of the participants. According to the results of Fig. 1, 63\% of the participants were male and $37 \%$ of them were female. In addition, most participants were middle-aged people. Approximately, $85 \%$ of the participants hold some university education. In addition, the results of Fig. 1 have indicated that most of the sales representative had less than 5 years of job experiences.

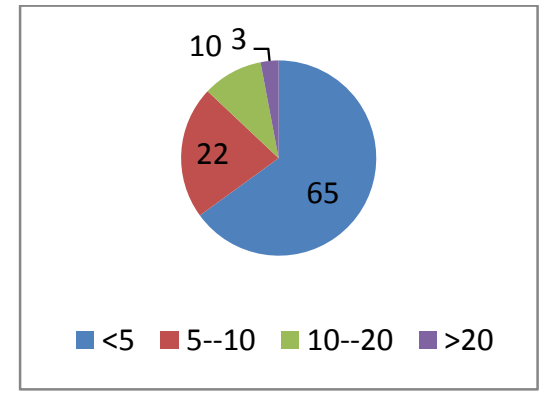

Years of job experiences

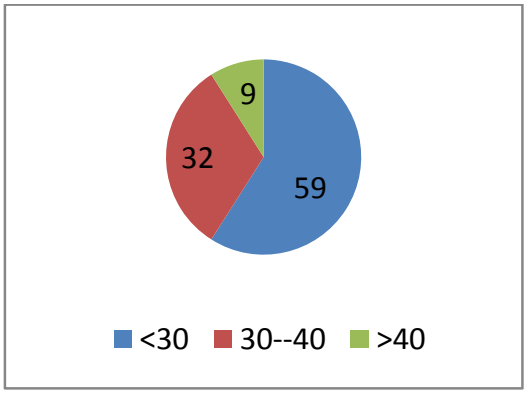

Age

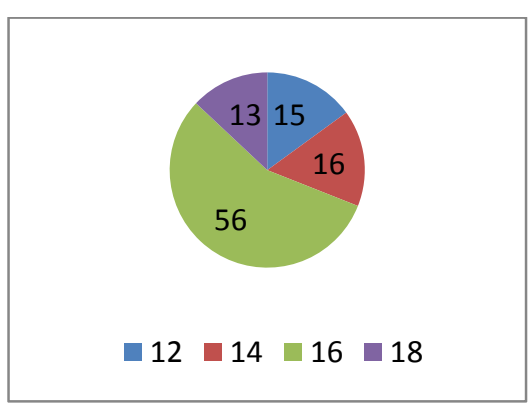

Years of education

Fig. 1. The summary of job experience, age and years of education

The study considers the effects of seven variables including qualification criteria, motivation, personality, empowering sales representative, information size, personal characteristics and sales interest in job on brand equity. Kaiser-Meyer-Olkin (KMO) measure of sampling adequacy along with Bartlett's test have been accomplished and the results are 0.879 and Chi-Square $=4554.141$ with Sig. $=0.000$. These results have indicated that the questionnaire is reliable and we may rely on to 
examine the hypotheses of the survey. Table 1 shows details of commonalities for 60 questions of the survey.

\section{Table 1}

The results of commonalities

\begin{tabular}{|c|c|c|c|c|c|c|c|c|}
\hline Attribute & Initial value & Extracted & Attribute & Initial value & Extracted & Attribute & Initial value & Extracted \\
\hline 8 & 1 & 0.573 & 31 & 1 & 0.637 & 46 & 1 & 0.554 \\
\hline 9 & 1 & 0.553 & 32 & 1 & 0.649 & 47 & 1 & 0.052 \\
\hline 13 & 1 & 0.616 & 33 & 1 & 0.595 & 48 & 1 & 0.584 \\
\hline 14 & 1 & 0.608 & 34 & 1 & 0.631 & 50 & 1 & 0.599 \\
\hline 16 & 1 & 0.527 & 35 & 1 & 0.007 & 51 & 1 & 0.521 \\
\hline 17 & 1 & 0.602 & 36 & 1 & 0.579 & 52 & 1 & 0.625 \\
\hline 20 & 1 & 0.688 & 37 & 1 & 0.661 & 53 & 1 & 0.539 \\
\hline 21 & 1 & 0.618 & 38 & 1 & 0.668 & 54 & 1 & 0.625 \\
\hline 25 & 1 & 0.069 & 39 & 1 & 0.627 & 56 & 1 & 0.677 \\
\hline 26 & 1 & 0.606 & 40 & 1 & 0.573 & 57 & 1 & 0.625 \\
\hline 27 & 1 & 0.637 & 41 & 1 & 0.535 & 60 & 1 & 0.583 \\
\hline 29 & 1 & 0.574 & 44 & 1 & 0.686 & & & \\
\hline 30 & 1 & 0.619 & 45 & 1 & 0.688 & & & \\
\hline
\end{tabular}

As we can observe from the results of Table 1, most values are well above 0.5 , which validates the overall questionnaire. We have removed some questions and applied principal component analysis and Table 2 shows details of the results after rotation has been applied.

Table 2

The summary of principal component analysis

\begin{tabular}{|c|c|c|c|c|c|c|c|c|c|c|}
\hline & \multicolumn{10}{|c|}{ Components } \\
\hline & 1 & 2 & 3 & 4 & 5 & 6 & 7 & 8 & 9 & 10 \\
\hline Information on inventory & .699 & & & & & & & & & \\
\hline Top management commitment & .565 & & & & & & & & & \\
\hline Training & .461 & .388 & .321 & .307 & & & & & & \\
\hline Performance & .716 & & & & & & & & & \\
\hline Behavior & 667 & & & & & & & & & \\
\hline Efforts & .498 & & & & & & & & & \\
\hline Word of mouth advertisement & .396 & .318 & & & & & & & & .317 \\
\hline Independent sales management & & .563 & & -.312 & & & & & .381 & \\
\hline Response to customers & & .485 & .336 & & & & & & & \\
\hline Job satisfaction & & .591 & & & & & & .334 & & \\
\hline Job security & & .615 & & & & & & & & \\
\hline Reputation & & .535 & & & & & & & & \\
\hline Skills & .356 & & .516 & & & & & & & \\
\hline Perception image & & & .714 & & & & & & & \\
\hline Work relationships & & & .676 & & & & & & & \\
\hline Innovative ideas & & & & .431 & & & 307 & .328 & & \\
\hline Technical knowledge & & & & .522 & & & 398 & & & \\
\hline Market knowledge & & & & .343 & & & .303 & & & \\
\hline Specialty & & & & .622 & & & & & & \\
\hline Capability & .320 & & & .510 & & & & & .376 & \\
\hline Flexible sales & & & & & .562 & & & .363 & & \\
\hline Updated knowledge & & & & & .674 & & & & & \\
\hline Formal rewards & & & & & .631 & .302 & & & & \\
\hline Loyalty & .341 & & .402 & & .553 & & & & & \\
\hline Quantity of information & & & & & & .793 & & & & \\
\hline Quality of information & & & & & & .689 & & & & \\
\hline Performance reflection & & & & -.345 & & .516 & & & & .365 \\
\hline Technology & & & & & & & .759 & & & \\
\hline Innovation & & & & & & & .707 & & & \\
\hline Information on competitors & & & & & & & & .648 & & \\
\hline Information on customers & & & & & & & & .677 & & \\
\hline Age & & & & & & & & & .668 & \\
\hline Residence against automated systems & & & & & & & & & .425 & .356 \\
\hline Gender & & & & & & & & & .794 & \\
\hline Region of work & & & & & & & & -.408 & & .483 \\
\hline Sales based on requirements & & & & & & & & .348 & & .356 \\
\hline Long term profitability & & & & & & & & & & .744 \\
\hline
\end{tabular}


The study extracted seven variables including qualification criteria, motivation, personality, empowering sales representative, information size, personal characteristics and sales interest in job on brand equity. Cronbach alphas for these components are 0.787, 0.834, 0.709, 0.731, 0.770, 0.731, 0.773 , respectively. These results validate the overall questionnaire. The results of some basic statistics are Chi-square $=544.47 ; \mathrm{RMSEA}=0.047 ; \mathrm{X}^{2} / \mathrm{df}=1.42 ; \mathrm{CFI}=0.98 ; \mathrm{IFI}=0.98 ; \mathrm{RFI}=0.92$; $\mathrm{AGFI}=0.86 ; \mathrm{NFI}=0.93$, which are within acceptable limits.

\section{The results}

Table 3 demonstrates the results of the implementation of structural equation modeling (SEM).

Table 3

The summary of SEM implementation

\begin{tabular}{|c|c|c|c|c|c|}
\hline Variable & loading Factor & T-Value & Variable & loading Factor & T-Value \\
\hline \multicolumn{3}{|c|}{ Qualification criteria } & \multicolumn{3}{|c|}{ Empowering sales representatives } \\
\hline 8 & 0.58 & 8.2 & 16 & 0.52 & 7.11 \\
\hline 20 & 0.42 & 5.72 & 25 & 0.28 & 3.64 \\
\hline 21 & 0.63 & 9.12 & 46 & 0.37 & 4.94 \\
\hline 9 & 0.55 & 7.7 & 47 & 0.64 & 8.96 \\
\hline 41 & 0.66 & 9.68 & 48 & 0.52 & 07.2 \\
\hline 14 & 0.59 & 8.35 & \multicolumn{3}{|c|}{ Personality } \\
\hline 33 & 0.71 & 10.55 & 34 & 0.67 & 9.28 \\
\hline \multirow{2}{*}{57} & \multirow{2}{*}{0.63} & \multirow{2}{*}{9.09} & 32 & 0.63 & 8.57 \\
\hline & & & 35 & 0.63 & 8.70 \\
\hline \multicolumn{3}{|c|}{ Sales' motivation } & \multicolumn{3}{|c|}{ Sales representatives' interest } \\
\hline 36 & 0.66 & 9.23 & 13 & 0.61 & 8.13 \\
\hline 37 & 0.61 & 8.45 & 17 & 0.69 & 9.46 \\
\hline 50 & 0.68 & 9.62 & 54 & 0.49 & 6.37 \\
\hline 51 & 0.51 & 6.88 & 60 & 0.54 & 7.14 \\
\hline \multicolumn{3}{|c|}{ Size of information } & \multicolumn{3}{|c|}{ Personal characteristics representatives } \\
\hline 38 & 0.63 & 8.59 & 40 & 0.6 & 7.78 \\
\hline 39 & 0.68 & 9.5 & 53 & 0.56 & 6.78 \\
\hline 52 & 0.59 & 8.03 & 56 & 0.53 & 6.78 \\
\hline
\end{tabular}

Next, we use the results of factor analysis to verify the effects of these seven factors on brand equity. The results of some basic statistics are Chi-square $=701.87$; RMSEA $=0.063 ; \mathrm{X}^{2} / \mathrm{df}=1.76 ; \mathrm{CFI}=$ $0.96 ; \mathrm{IFI}=0.96 ; \mathrm{RFI}=0.91 ; \mathrm{AGFI}=0.87 ; \mathrm{NNFI}=0.93$, which are within acceptable limits.

\section{Discussion and Conclusion}

The implementation of structural equation modeling has provided us good insight to examine the effects of seven important factors influencing on brand equity. Table 4 shows details of our findings on testing the hypotheses of the survey.

\section{Table 4}

The results of structural equation modeling

\begin{tabular}{lcccccccc}
\hline Relationship & $\beta$ & Standard $\beta$ & Standard error & t-value & R-Square & P-Value & Result \\
\hline Qualification criteria $\rightarrow$ Brand equity & 0.8 & 0.80 & 0.11 & 7.1 & 0.64 & $\mathrm{P}<0.01$ & Confirmed \\
Sales motivation $\rightarrow$ Brand equity & 0.72 & 0.72 & 0.1 & 6.89 & 0.52 & $\mathrm{P}<0.01$ & Confirmed \\
Personality $\rightarrow$ Brand equity & 0.74 & 0.74 & 0.11 & 6.76 & 0.54 & $\mathrm{P}<0.01$ & Confirmed \\
Empowering sales representative $\rightarrow$ Brand equity & 1.03 & 1.03 & 0.12 & 8.42 & 0.98 & $\mathrm{P}<0.01$ & Confirmed \\
Quantity of information $\rightarrow$ Brand equity & 0.76 & 0.76 & 0.11 & 6.77 & 0.57 & $\mathrm{P}<0.01$ & $\mathrm{Confirmed}$ \\
Personal characteristics $\rightarrow$ Brand equity & 0.66 & 0.66 & 0.12 & 5.52 & 0.44 & $\mathrm{P}<0.01$ & Confirmed \\
Sales representative motivation $\rightarrow$ Brand equity & 0.71 & 0.71 & 0.12 & 6.03 & 0.51 & $\mathrm{P}<0.01$ & Confirmed \\
\hline
\end{tabular}


According to the results of Table 4, all seven factors influence on brand equity, positively. The highest impact belongs to empowering sales representative followed by qualification criteria, quantity of information, personality and sales motivation.

The results of our findings are consistent with findings of Hawkins et al. (2013), Holmes and Srivastava (2002), Honeycutt Jr et al. (2005), Keillor et al. (1997), Keller (1993), Rangarajan et at. (2005), Ram and Jung (1991) and Aaker (1990, 2008, 2009, 2012).

\section{Acknowledgement}

The authors would like to thank the anonymous referees for constructive comments on earlier version of this paper.

\section{References}

Aaker, D. A., \& Keller, K. L. (1990). Consumer evaluations of brand extensions. Journal of marketing, 54(1).

Aaker, D. A. (2008). Strategic market management. John Wiley \& Sons.

Aaker, D. A. (2009). Managing brand equity. Simon and Schuster.

Aaker, D. A. (2012). Building strong brands. Simon and Schuster.

Anderson, P. F. (1982). Marketing, strategic planning and the theory of the firm. The Journal of Marketing, 46(2), 15-26.

Bente, G., Baptist, O., \& Leuschner, H. (2012). To buy or not to buy: Influence of seller photos and reputation on buyer trust and purchase behavior. International Journal of Human-Computer Studies, 70(1), 1-13.

Barker, R. M., Gohmann, S. F., Guan, J., \& Faulds, D. J. (2009). Why is my sales force automation system failing?. Business Horizons, 52(3), 233-241.

Buehrer, R. E., Senecal, S., \& Bolman Pullins, E. (2005). Sales force technology usage-reasons, barriers, and support: An exploratory investigation. Industrial Marketing Management, 34(4), 389398.

Cascio, R., Mariadoss, B. J., \& Mouri, N. (2010). The impact of management commitment alignment on salespersons' adoption of sales force automation technologies: An empirical investigation. Industrial Marketing Management, 39(7), 1088-1096.

Cho, S. D., \& Chang, D. R. (2008). Salesperson's innovation resistance and job satisfaction in intraorganizational diffusion of sales force automation technologies: the case of South Korea. Industrial Marketing Management, 37(7), 841-847.

Franke, G. R., \& Park, J. E. (2006). Salesperson adaptive selling behavior and customer orientation: a meta-analysis. Journal of Marketing Research, 43(4), 693-702.

Gohmann, S. F., Guan, J., Barker, R. M., \& Faulds, D. J. (2005). Perceptions of sales force automation: Differences between sales force and management. Industrial Marketing Management, 34(4), 337-343.

Hawkins, D. I., Mothersbaugh, D. L., \& Best, R. J. (2013). Consumer behavior: Building marketing strategy. McGraw-Hill Irwin.

Holmes, T. L., \& Srivastava, R. (2002). Effects of job perceptions on job behaviors: implications for sales performance. Industrial Marketing Management, 31(5), 421-428.

Honeycutt Jr, E. D., Thelen, T., Thelen, S. T., \& Hodge, S. K. (2005). Impediments to sales force automation. Industrial Marketing Management,34(4), 313-322.

Keillor, B. D., Bashaw, R. E., \& Pettijohn, C. E. (1997). Salesforce automation issues prior to implementation: the relationship between attitudes toward technology, experience and productivity. Journal of Business \& Industrial Marketing, 12(3/4), 209-219.

Keller, K. L. (1993). Conceptualizing, measuring, and managing customer-based brand equity. The Journal of Marketing, 57(1), 1-22. 
1524

Ram, S., \& Jung, H. S. (1991). "Forced" adoption of innovations in organizations: consequences and implications. Journal of Product Innovation Management, 8(2), 117-126.

Rangarajan, D., Jones, E., \& Chin, W. (2005). Impact of sales force automation on technology-related stress, effort, and technology usage among salespeople. Industrial Marketing Management, 34(4), 345-354. 